\title{
MORPHOMETRY AND MORPHOLOGY OF NUCLEUS OF THE SERTOLI AND INTERSTITIAL CELLS OF THE TAMBAQUI Colossoma macropomum (CUVIER, 1881) (PISCES: CHARACIDAE) DURING THE REPRODUCTIVE CYCLE
}

\author{
NAKAGHI, L. S. O., ${ }^{1,2}$ MITSUIKI, D., ${ }^{2}$ SANTOS, H. S. L., ${ }^{1}$ \\ PACHECO, M. R. ${ }^{1}$ and GANECO, L. N. ${ }^{2}$ \\ ${ }^{1}$ Departamento de Morfologia e Fisiologia Animal, Faculdade de Ciências Agrárias e Veterinárias, UNESP, Via de \\ Acesso Paulo Donato Castellane, km 05, CEP 14884-900, Jaboticabal, SP, Brazil \\ ${ }^{2}$ Centro de Aqüicultura da UNESP, Jaboticabal, SP, Brazil \\ Correspondence to: Laura Satiko Okada Nakaghi, Departamento de Morfologia e Fisiologia Animal, Faculdade de \\ Ciências Agrárias e Veterinárias, UNESP, Via de Acesso Paulo Donato Castellane, km 05, CEP 14884-900, \\ Jaboticabal, SP, Brazil, e-mail: laurankg@ fcav.unesp.br \\ Received December 6, 2001 - Accepted Juny 21, 2002 - Distributed February 28, 2003
}

(With 1 figure)

\begin{abstract}
This study allowed the characterization of the tambaqui Colossoma macropomum testes structural organization, emphasizing Sertoli and interstitial cells and analyzing morphometrically the Sertoli cell nucleus diameter and the interstitial tissue area during the reproductive cycle. Fragments of tambaqui testes were collected in the following reproductive cycle stages: immature, resting, maturation I and II, mature, and regression, and were histologically processed. The Sertoli cells were found at the periphery of the cysts of germinative lineage cells and the nuclei were shown to be smaller as these cells developed. The interstitial cells were better observed between the seminiferous lobules next to vessels in the interstitial tissue of maturing testes.
\end{abstract}

Key words: Colossoma macropomum, Sertoli cells, interstitial tissue, morphometry, morphology.

\section{RESUMO}

\section{Morfometria e morfologia do núcleo das células de Sertoli e intersticiais do tambaqui} Colossoma macropomum (Cuvier, 1881) (Pisces: Characidae), durante o ciclo reprodutivo

Este trabalho permitiu caracterizar a organização estrutural dos testículos de tambaqui Colossoma macropomum, com ênfase às células de Sertoli e intersticiais, bem como analisar morfometricamente o diâmetro dos núcleos das células de Sertoli e a área do tecido intersticial, durante o ciclo reprodutivo. Fragmentos de testículos de tambaqui foram coletados nos seguintes estádios do ciclo reprodutivo: imaturo, repouso, maturação I e II, maduro e regressão, e processados histologicamente. As células de Sertoli se apresentaram na periferia dos cistos de células germinativas, e com o desenvolvimento das mesmas seus núcleos ficavam cada vez menores. As células intersticiais foram melhor evidenciadas entre os lóbulos seminíferos, ao lado de vasos sanguíneos no tecido intersticial dos testículos em maturação.

Palavras-chave: Colossoma macropomum, célula de Sertoli, tecido intersticial, morfometria, morfologia. 


\section{INTRODUCTION}

During gonadal development, the testis presents more discreet variations than do ovaries. These variations relate to weight, volume, shape, and coloration. In that period, the testis presents seminiferous lobules having spherical or oval cysts inside of which the spermatogenic lineage cells develop. In each cyst, all germinative cells are in the same developmental phase and Sertoli cells in variable number envelop them.

During the reproductive cycle the Sertoli cells occur in variable forms mainly relat to the morphology of nucleus and cytoplasm. These cells constitute the somatic envelope of spermatogenic lineage cells, distributed in the cysts' peripheral area.

Different nomenclature has been used for Sertoli cells. Researchers have termed them "cells of connective tissues" (Bhatti \& Al-Daham, 1978); "peripheral cells or lobule boundary cells" (Marshall \& Lofts, 1956; Yaron, 1966; Upadhyay \& Guraya, 1971; Grier, 1976; Nagahama et al., 1978); "folicular cells" (Weisel, 1943; Lofts et al., 1966); "fellow cells" (Ruby \& McMillian, 1975); "special Sertoli cells" (Gresik, 1973; Billard et al., 1982); "cyst cells" (Roosen Runge, 1977; Agostinho, 1985); "intralobular cyst cells" (Borges Filho, 1987); and "Sertoli cells" (Nicholls \& Graham, 1972; Nagahama, 1983; Cruz-Höfling \& Cruz-Landim, 1984; Silva, 1987).

In spite of the Roosen Runge (1977) and Billard et al. (1982) terminology for teleosts, we consider the term "cyst cells" more appropriate; the expression Sertoli cell is used here due to the homology with mammalian Sertoli cells (Mitsuiki, 2002).

Taking into account the function of Sertoli cells, authors like Grier \& Linton (1977) and CruzHöfling \& Cruz-Landim (1984) have established a relationship between lipid presence in Sertoli cells and steroidogenic activity. On the other hand, Mattei et al. (1982) have suggested that if such cells do not synthesize steroids, at least they are the storage site of these hormones. Another function related to Sertoli cells is gametic phagocytosis, mainly in the testes of the pacu Piaractus mesopotamicus when maintained in captivity. This fact might be related to unnatural elimination of spermatozoids, which consequently degenerate and are reabsorbed (Romagosa, 1991).
In spite of the term "interstitial cells" being the most widely used for fish, according to Fostier et al. (1983) some discrepancies exist related to this terminology as applied to these cells. The interstitial cells have been variously termed: "lobule boundary cells", "homologous cells of Leydig" (Marshall \& Lofts, 1956; Lofts \& Marshall, 1957; Gresik et al., 1973), and "Sertoli cells" (Stanley et al., 1965; Nicholls \& Graham, 1972).

Several authors have suggested that the "Leydig cells" are involved in steroidogenic activity. They may either synthesize or accumulate secretion products or do both (Marshall \& Lofts, 1956; Oota \& Yamamoto, 1966; Billard et al., 1971; Nicholls \& Graham, 1972; Grier et al., 1980; Nagahama, 1983; Cruz-Höfling \& Cruz-Landim, 1984; Borges Filho, 1987).

Although several studies have analyzed the morphology of both interstitial cells and Sertoli cells as well as their roles, research is still necessary on the structure and morphometrey of these cells in different stages of the reproductive cycle and, particularly, on the interstitial cells of teleost testes. Until now, these have been not well characterized. Our study therefore aims to analyze these features of the tambaqui Colossoma macropomum.

\section{MATERIAL AND METHODS}

Tambaqui Colossoma macropomum males were collected in ponds of the Aquaculture Center, State University of São Paulo (UNESP-CAUNESP, Jaboticabal, SP), and of the Power Station of Minas Gerais (CEMIG, Conceição das Alagoas, MG), at the following reproductive cycle stages of the: immature, resting, maturation I, maturation II, mature, and regression. After sampled, each fish was weighed (total weight) and measured (total length and standard length). The animals were sacrificed by spinal cord destruction and ventrally incised gonad for analysis and extirpation. Gonads were weighed and samples of cranial, medial, and caudal portions taken. They were fixed in Bouin's solution for 6 hours at $4^{\circ} \mathrm{C}$ and for 24 hours at ambient temperature. Inclusion of the samples was done in paraffin. Cross-sectioning was $6 \mu \mathrm{m}$ thickness and staining was by the hematoxilin techniques of Harris-eosin (HE), Periodic Acid Schiff (PAS), and Masson's Tricromic (MT). All these procedures, used to get a histological crosssection of the studied testes, were carried out at 
the Laboratory of Fish Histology of the Department of Morphology and Animal Physiology (Agronomic and Veterinary Sciences College, Jaboticabal, UNESP).

The area of the nucleus of intralobular Sertoli cells and interstitial tissue, located among three seminiferous lobules of testes in stages of maturation I and II of the reproductive cycle, was calculated using an Image Analyzer System (Videoplan - Image Analysis Kontron Elektronik - Zeiss). Measures were done in 30 nuclei of Sertoli cells, located alongside each type of testicular germinal cell, resulting in a total of 150 Sertoli cells (per animal and per developmental stage), for which the nuclear areas were determined. Comparisons were done among samples of cranial, medial, and caudal regions. The triangular areas, occupied by interstitial tissue, were measured in the same way as that of the cyst cell nucleus, i.e., using a $40 \mathrm{x}$ objective. Basically, 240 interstitial areas and 120 for each maturation stage were measured. Data obtained by measurements done through the Image Analyzer System were analyzed by Test F, and mean values were compared by Tukey test.

\section{RESULTS}

In the histological preparations of tambaqui testes no differences among the cephalic, medial and caudal regions were oberved.

A testes in the immature stage of the reproductive cycle consisted of small seminiferous lobules and much interstitial tissue. Primary spermatogonia were found throughout the lobules and characterized as cells having a spherical centrally located nucleus with a single nucleolus (Fig. 1A).

In the resting stage, the seminiferous lobules were bigger and contained several spermatogonia (primary and secondary) (Fig. 1B). In these lobules, interstitial tissue was less abundant.

In testes in maturation I (Fig. 1C) the following structures were identified: isolated primary spermatogonia; secondary spermatogonia cysts; spermatocyte (I and II) cysts; spermatid cysts; and some spermatozoids in seminiferous lobule lumen and interstitial tissue, which were clearly seen in areas where three or more lobules were fitted together.

In testes in maturation II (Fig. 1D), the seminiferous lobules appeared big and had several spermatozoids in their lumen. Interstitial tissue was evident among the lobules, mainly where three of them were joined. Primary spermatogonia and the cysts of the other germ cells were also present in this reproductive cycle.

Mature testes showed lobules full of spermatozoids, with spermatogonia surrounding them, and a thin interstitial tissue layer among them (Fig. 1E).

Testes in regression showed irregular seminiferous lobules, with several spermatogonia and some residual spermatozoids. The interstitial tissue was very abundant among the seminiferous lobules (Fig. 1F).

In several analyzed testes, Sertoli cells were found within the seminiferous lobules, beside the primary spermatogonia and at the periphery of several germ cell cysts. Sertoli cell nuclei located near the primary spermatogonia (Fig. 1C) appeared bigger and wider, and triangular or egg-shaped. Some nuclei appeared more elongated, in accordance with the profile of each spermatogonia. Testis in maturation I and II showed Sertoli cells making up a somatic envelope of several germ cell cysts (Fig. 1C). They showed a flattened nucleus and thin cytoplasmatic extensions. Such nuclei appeared increasingly flat as testes developed further.

Interstitial cells were better evidenced in testes in maturation I and II, mainly in Maturation I. They were identified in interstitial tissue, located among the seminiferous lobules. Interstitial cells were better visualized in triangular areas, containing interstitial tissue and formed by three adjacent lobules, always alongside the blood vessels.

Interstitial cell cytoplasmatic borders were not well defined, thus making it difficult to recognize the eccentric position of the nucleus, which was egg-shaped.

Statistical analyses showed that the Sertoli cell nuclear area, situated beside the primary spermatogonium, was bigger than the nuclear area of the same cell, producing a somatic envelope of diverse germ cell cysts $(\mathrm{p}<0.01)$ (Table 1$)$.

The nuclear Sertoli cell area, located near the primary spermatogonia, was bigger in testes in maturation II when compared with that of maturation I $(\mathrm{p}<0.05)$. In the secondary spermatogonia, the Sertoli cell nuclear areas showed no significant difference in testes in maturation I and II. 

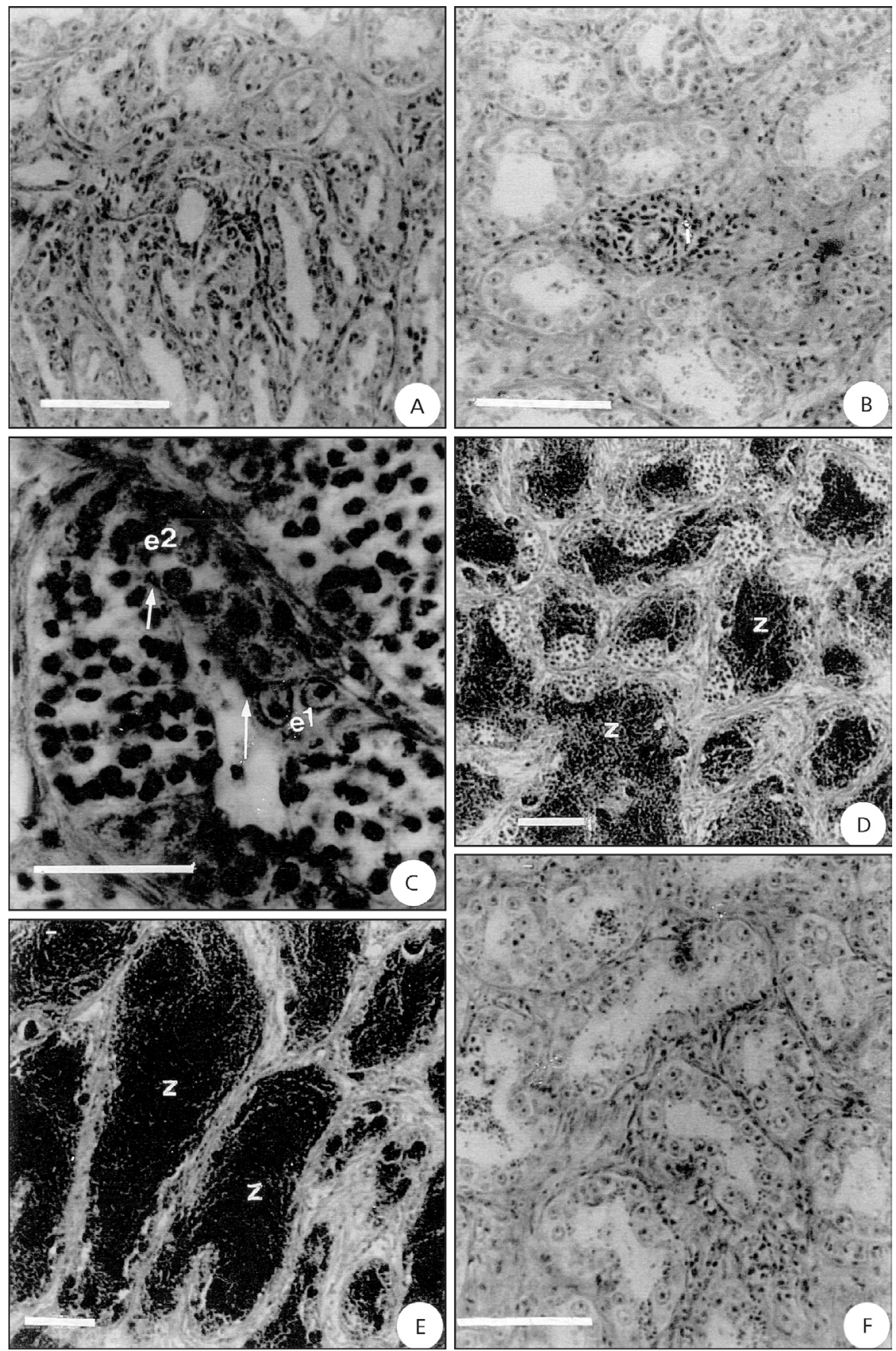

Fig. 1 - Photomicrograph of the testes of tambaqui C. macropomum (MT). A. Immature stage, showing primary spermatogonia throughout the lobules. Bar $=10 \mu \mathrm{m}$; B. Resting stage, showing several spermatogonia (primary and secondary) and interstitial cells (i). Bar $=10 \mu \mathrm{m}$. C. Maturation I stage, evidencing Sertoli cell nuclei (arrow) beside the primary spermatogonia $\left(\mathrm{e}_{1}\right)$ and cysts of the secondary spermatogonia $\left(\mathrm{e}_{2}\right)$. Bar $=5 \mu \mathrm{m}$. D. Maturation II stage, evidencing seminiferous lobules with cyst cells and spermatozoids $(\mathrm{z})$. Bar $=10 \mu \mathrm{m}$. E. Mature stage, full of spermatozoids (z). Bar $=10 \mu \mathrm{m}$. F. Regression stage, evidencing primary spermatogonia $\left(\mathrm{e}_{1}\right)$, secondary spermatogonia $\left(\mathrm{e}_{2}\right)$ and residual spermatozoids $(\mathrm{z}) . \mathrm{Bar}=10 \mu \mathrm{m}$. 
TABLE 1

Value of the F-test of the Sertoli cell nuclear area in maturation I (Mat I) and II (Mat II).

\begin{tabular}{|l|c|c|c|c|c|}
\hline Stage & $\begin{array}{c}\text { Primary } \\
\text { spermatogonia }\end{array}$ & $\begin{array}{c}\text { Secondary } \\
\text { spermatogonia }\end{array}$ & $\begin{array}{c}\text { Spermatocyte } \\
\text { I }\end{array}$ & $\begin{array}{c}\text { Spermatocyte } \\
\text { II }\end{array}$ & Spermatid \\
\hline Mat I & $13.4433 \mathrm{~A}^{*}$ & $10.4258 \mathrm{~A}$ & $7.9950 \mathrm{a}$ & $6.8975 \mathrm{a}$ & $5.3575 \mathrm{a}$ \\
\hline Mat II & $15.1525 \mathrm{~B}$ & $10.6758 \mathrm{~A}$ & $9.4650 \mathrm{~b}$ & $6.0692 \mathrm{~b}$ & $3.8325 \mathrm{~b}$ \\
\hline & $\mathrm{Sd}=1.532$ & $\mathrm{Sd}=0.751$ & $\mathrm{Sd}=0.683$ & $\mathrm{Sd}=0.359$ & $\mathrm{Sd}=0.397$ \\
\hline
\end{tabular}

* Values followed by capital letters differ by $5 \%$ significance level; values followed by small letters differ by $1 \%$ significance level $(n=4)$, standard deviation $(\mathrm{Sd})$.

In spermatocytes I, the Sertoli cell nuclear area showed a significant difference in testes in maturation I and II $(\mathrm{p}<0.01)$, so that in maturation I the difference was bigger than in stage II. Spermatocytes II showed a significant difference in the Sertoli cell nuclear area of the testes in maturation I and II $(\mathrm{p}<0.01)$ and in maturation I the difference was bigger than in stage II. At the periphery of the spermatid cysts, the Sertoli cell nuclear area was significantly different in testes in maturation I and II ( $\mathrm{p}<0.01)$, and was bigger in maturation I (Table 1).

The Sertoli cell nuclear area related with primary spermatogonium and producing the sheathing of several intralobular cysts of germ cells, showed no significant difference among the sampled testes in the cranial, medial, and caudal regions.

The statistical analysis applied to interstitial tissue area data (Table 2) evidenced a significant difference $(\mathrm{p}<0.05)$ in testes in two maturation stages: maturation I the difference was bigger than in maturation II $(\mathrm{p}<0.05)$.

The area occupied by the interstitial tissue located among three seminiferous lobules of testes in maturation I and II did not show any difference among the regions in which the samples were taken (cranial, medial, and caudal).

\section{DISCUSSION}

In the testes of tambaqui no histological differences among the cephalic, medial, and caudal regions were observed. According to Romagosa (1991), the same was true for pacu. Testes of tambaqui fit the first pattern of classification described by Grier et al. (1980) (spermatogonial unrestricted), since the spermatogonia lie alongside the entire seminiferous lobule.

TABLE 2

Mean values of the statistical analysis, comparing areas $\left(\mu \mathrm{m}^{2}\right)$ of interstitial tissue located among three seminiferous lobules.

\begin{tabular}{|l|c|}
\hline \multicolumn{1}{|c|}{ Maturation Stage } & Mean $\left(\mu \mathbf{m}^{\mathbf{2}}\right)$ \\
\hline Regression & $2181.7225 \mathrm{~A}$ \\
\hline Immature & $629.92 \mathrm{~B}$ \\
\hline Resting & $615.79 \mathrm{~B}$ \\
\hline Maturation I & $439.92 \mathrm{C}$ \\
\hline Maturation II & $358.95 \mathrm{CD}$ \\
\hline Mature & $288.3225 \mathrm{D}$ \\
\hline
\end{tabular}

Tukey test; $\mathrm{n}=6$; variation coefficient $=6.95$; values followed by different letters differ by $1 \%$ significance level. 
The primary spermatogonia of tambaqui were considered the biggest cells of the germinative lineage. They occured individually in seminiferous lobules, distributed throughout the testes, during all reproductive cycle phases. These morphological observations are in accordance with those of Romagosa (1991).

Secondary spermatogonia, observed in tambaqui testes appeared inside the cysts. They were small cells with more condensed chromatin and their morphology is similar to that described by Silva (1987) and Romagosa (1991), for species they studied. These cells result from mitotic division of primary spermatogonia later transformed into spermatocytes I.

Until now, there is no literature regarding Sertoli cell karyometry of teleost fish gonads.

Agostinho et al. (1987) and Billard et al. (1972) studied Rhinelepesis aspera and Onchorhinchus mykiss, respectively, and reported that Sertoli cells have their nuclei modified during the spermatogenic process. The nuclei of these cells appeared bigger and almost spherical in testes in resting, and smaller and elongated in testes in maturation. In mature testes, the nucleus of the Sertoli cells can be entangled in the tubular wall.

Zaiden (1997, 2000) studied Brycon orbignyanus and Brycon hilari respectively and verified that Sertoli cell nuclei became more and more elongated as spermatogenic lineage developed.

Data presented in Table 1 shows that in tambaqui, the nucleus narrowed during development, in accordance with the results obtained by Zaiden (1997, 2000). The size of Sertoli cell nuclei did not differ statistically among the three studied regions (cranial, medial and caudal).

The analyses resulted in the following conclusions: the testes of tambaqui Colossoma macropomum are composed of several types of germinative cells (primary spermatogonia, secondary spermatogonia, spermatocyte I, spermatocyte II, spermatid, and spermatozoid). The primary spermatogonium is the biggest germinative cell and the spermatozoid is the smallest. Primary spermatogonia and spermatozoid did not produce cysts. Primary spermatogonia are distributed throughout the seminiferous lobule and are isolated, while spermatozoid lie in the lobule lumen. Sertoli cells constitute the somatic envelope of germinative cells, from secondary spermatogonia to spermatids (they are also found beside primary spermatogonia and their nucleus decreases in size and changes in shape during spermatogenic cell development). Interstitial cells are clearly in evidence in testes at the beginning of maturation and are always located beside blood vessels, characterizing the beginning of a new reproductive cycle. At this point, the steroids necessary to testes development have been synthetized. Furthermore, the area development have been synthesize. Furthermore, the area occupied by interstitial tissue diminishes with testicular development.

In fish, the sign that the Sertoli cell participates in steroid synthesis is the presence of organelles such as smooth endoplasmic reticules, mitochondria with tubular crista, and cytoplasmatic lipids (Nicholls \& Graham, 1972; Gresik et al., 1973; Van der Hurk et al., 1975; Grier \& Linton, 1977; Grier et al., 1989; Van Vurey \& Soley, 1990; Guraya, 1994; Andrade et al., 2001).

The Sertoli cells found in tambaqui testes presented bigger nuclei in the resting period, becoming flat in the maturation period, due to the modifications undergone in the formation of spermatogenic cysts. Romagosa (1991) found a triangularly-shaped cyst cell nuclei in Piaractus mesopotamicus. Cecílio \& Agostinho (1991) showed that the same nuclei in Hypotalmus edentatus are comma-shape, changing to rod-shape with gonadal maturation. Zaiden (2000) showed in piraputanga testes, that this cell has an oval nucleus in the resting period, gradually flattening in the maturation period.

A great variety of information exists on Sertoli cells in fish, describing, e.g., there function and employin differing nomenclature, but controversies are not few, making necessary many more studies to obtain histophysiological information that will show their role in the tambaqui's reproductive cycle and contribute to further understanding the reproductive cycle of these species, which is of great importance in aquaculture. 
Acknowledgments - The authors are grateful to FAPESP (process 95/9261-1) and Mr. Orandi Mateus for their technical assistance.

\section{REFERENCES}

AGOSTINHO, A. A., 1985, Estrutura da população, idade, crescimento e reprodução de Rhinelepsis aspera (Agassiz, 1829) (Osteichthyes, Loricaridae) do rio Paranapanema, $P R$. Tese de Doutorado em Ecologia e Recursos Naturais, Universidade Federal de São Carlos, São Carlos, 229p.

Agostinho, A. A., BARBIERI, M. C., AGOSTINHO, C. S. \& BARBIERI, G., 1987, Biologia reprodutiva de Rhinelepis aspera (Agassiz, 1829) (Teleostei, Loricariidae) no rio Paranapanema. I. Estrutura dos testículos e escala de maturidade. Rev. Bras. Biol., 47(3): 309-317.

ANDRADE, R. F., BAZOLLI, N., RIZZO, E. \& SATO, Y., 2001, Continuous gametogenesis in the neotropical freshwater teleost, Bryconops affinis (Pisces: Characidae). Tiss. Cell., 33(5): 524-532.

BHATTI, M. N. \& AL-DAHAM, N. K., 1978, Annual cyclical changes in the testicular activity of a freshwater teleost, Barbus luteus (Heckel) from Shatt-al-Arab, Iraq. J. Fish Biol., 13(3): 321-326.

BILLARD, R., JALABERT, B. \& BRETON, B., 1972, Les cellules de Sertoli des poisson téléostéens, Ann. Biol. Anim. Bioch. Biophys, 12(1): 19-32.

BILLARD, R., FOSTIER, A., WELL, C. \& BRETON, B., 1982, Endocrine control of spermatogenesis in teleost fish. Can. J. Fish Aquat. Sci., 39: 65-79.

BILLARD, R., MEUSY-DESSOLES, N. \& FLECHON, J. E., 1971, Les cellules interstielles de quelques Poissons téléostéens (abstr.). J. Microscopie, 11: 30.

BORGES FILHO, O. F., 1987, Caracterização dos estádios de maturação e correlação com avaliações histoquímicoenzimáticas e ultra-estruturais das células endócrinas testiculares, durante o ciclo reprodutivo do Prochilodus scrofa - Steindachener, 1881. Tese de Doutorado em Ciências-Fisiologia, Universidade de São Paulo, São Paulo, 233p.

CECÍllO, E. B. \& AGOSTINHO, A. A., 1991, Biologia reprodutiva de Hypophthalmus edentatus (Spix, 1829) (Osteichtyes, Siluriformes) no reservatório de Itaipu PR. I. Estrutura dos testículos e escala de maturidade. Unimar, 13(2): 195-209.

CRUZ-HÖFLING, M. A. \& CRUZ-LANDIM, C., 1984, Ultrastructural and histochemical studies on the Leydig and Sertoli cell homologues in the testis of Triportheus elongatus (Sardinhão) and Mylssoma aureum (Panu). Cytobios, 41: 161-174.

FOSTIER, A., JALABERT, B., BILLARD, R., BRETON, B. \& ZOHAR, Y., 1983, The gonad steroids. In: W. S. Hoar, D. J. Randall \& E. M. Donaldson (eds.), Fish physiology. New York, Academic Press, v. 9, part A, pp. 277-372.
GRESIK, E. W., 1973, Fine structural evidence for the presence of nerve terminals in the testis of the teleosts, Oryzias latipes. Gen Comp. Endocrinol, 21: 210-213.

GRESIK, E. W., QUIRK, J. G. \& HAMILTON, J. B., 1973, A fine structural and histochemical study of the Leydig cell in the testis of the teleost, Oryzias latipes (Cyprinidontiformes). Gen. Comp. Endocrinol., 20: 8698.

GRIER, H. J., 1976, Sperm development in the teleost Oryzias latipes. Cell Tiss. Res., 168: 419-432.

GRIER, H. J. \& LINTON, J. R., 1977, Ultrastructural identification of the Sertoli cell in the testis of the northern pike, Esox lucius. Amer. J. Anat., Philadelphia, 149: 283-288.

GRIER, H. J., LINTON, J. R., LEATHERLAND, J. F. \& VLAMING, V. L., 1980, Structural evidence for two different testicular types in teleosts fishes. Amer. J. Anat., 159: 331-345.

GRIER, H. J., VAN DER HURK, R. \& BILLARD, R., 1989, Cytological identification of cell types in the testis of Esox lucius and E. niger. Cell Tissue Res., 257: 491-496.

GURAYA, S. S., 1994, Gonadal development and production of gamete in fish. Proc. Indian Nat. Sci Acad., 1: 15-32.

LOFTS, B. \& MARSHALL, A. J., 1957, Cyclical changes in the distribution of the testis lipids of a teleost fish Esox lucius. Quart. J. Microscop. Sci., 98: 79-88.

LOFTS, B., PICKFORD, G. E. \& ATZ, J. W., 1966, Effects of a hypophysectomized fish, Fundulus heteroclitus. Gen. Comp. Endocrin., 6: 74-88.

MARSHALL, A. J. \& LOFTS, B., 1956, The Leydig-cell homologue in certain teleosts fishes. Nature, London, 177: 704-705.

MATTEI, X., MATTEI, C., MARCHAND, B. \& KIT, D. L. T., 1982, Ultrastructure de cellules de Sertoli d'un poisson téléostéen: Abudeful marginatus. J. Ultraestr. Res., 81: 333-340.

MITSUIKI, D., 2002, Aspectos morfofuncionais das células de Sertoli de peixes teleósteos. Dissertação de Mestrado em Aqüicultura, Centro de Aqüicultura da UNESP, CAUNESP, Jaboticabal, 42p.

NAGAHAMA, Y., 1983, The functional morphology of the teleost gonads. In: W. S. Hoar \& D. J. Randall (eds.), Fish physiology. New York, Academic Press, v. 9, part A, pp. 233-275.

NAGAHAMA, Y., CLARKE, W. C. \& HOAR, W. S., 1978, Ultrastructure of putative steroid-producing cells in the gonads of coho (Oncorhynchus kisutch) and pink salmon (Oncorhynchus gorbuscha). Can. J. Zool., 56: 2508-2519.

NICHOLLS, T. J. \& GRAHAM, G. P., 1972, The ultrastructure of lobule boundary cells and Leydig cell homologs in the testis of a cichlid, Cichlasoma nigrofasciatum. Gen. Comp. Endocrinol., 19: 133-146. 
OOTA, I. \& YAMAMOTO, K., 1966, Interstitial cells in the immature tests of the rainbow trout. Annotiones Zool. Jap., Tokyo, 39: 142-148.

ROMAGOSA, E., 1991, Mudanças morfológicas (microscopia de luz e eletrônica) das gônadas do pacu Piaractus mesopotamicus (Holmberg, 1887) durante o ciclo reprodutivo, em condições de confinamento. Tese de Doutorado em Ciências Biológicas, Universidade Estadual Paulista, Rio Claro, 177p.

ROOSEN RUNGE, E. C., 1977, The process of spermatogenesis in animals. Cambridge Univ. Press, Cambridge, London, New York, Melbourne.

RUBY, S. M. \& McMILLIAN, D. B., 1975, The interstitial origin of germinal cell in the testis of stickleback. $J$. Morph., Philadelphia, 145: 295-318.

SILVA, M., 1987, Morfologia ultra-estrutural do testículo, cinética da espermatogênese e barreira hemotesticular da tilápia do Nilo, Oreochromis niloticus (Peixe, Ciclídeo). Tese de Doutorado em Ciências-Morfologia, Universidade Federal de Minas Gerais, Belo Horizonte, 164p.

STANLEY, H., CHIEFFI, G. \& BOTTE, V., 1965 , Histological and histochemical observations on the testis of Gobius paganellus. Z. Zellforsch, 65: 350-362.

UPADHAYAY, S. N. \& GURAYA, S. S., 1971, Histochemical observations on the interstitial tissue of fish testis. Gen. Comp. Endocrinol., 16: 504-510.
VAN DER HURK, R., PEUTE, J., MEEK, J. \& VAN OORDT, P. G. W. J., 1975, The Sertoli cell in the testis of the black molly (Mollienisia latipinna). J. Endocrinol., 64: 39-40.

VAN VUREY, J. H. J. \& SOLEY, J. T., 1990, Some ultrastructural observations of Leydig and Sertoli cells in the testis of tilapia Tilapia rendalli following induced testicular recrudescence. J. Morph., 206: 57-63.

WEISEL, G. E., 1943, A histological study of the testis of the Sockeyed salmon Oncorhynchus neka. J. Morph., Philadelphia, 73: 207-230.

YARON, Z., 1966, Demonstration of 3B-hydorxysteroid dehydrogenase in the testis of Tilapia mossambica (Cichlidae, Teleostei). J. Endocrinol., 34: 127-128.

ZAIDEN, S. F., 1997, Estrutura testicular da piracajuba Brycon orbignyanus (Valencienes, 1849) (Pisces, Characidae), nos vários estádios do ciclo sexual. Dissertação de Mestrado em Aqüicultura, Centro de Aqüicultura da UNESP, CAUNESP, Jaboticabal, 71p.

ZAIDEN, S. F., 2000, Morfologia gonadal e metabolismo energético da piraputanga Brycon hilarii (Cuvier $e$ Valenciennes, 1849) (Pisces, Characidade), em cativeiro, durante o ciclo reprodutivo anual. Tese de Doutorado em Aqüicultura, Centro de Aqüicultura da UNESP, CAUNESP, Jaboticabal, 152p. 